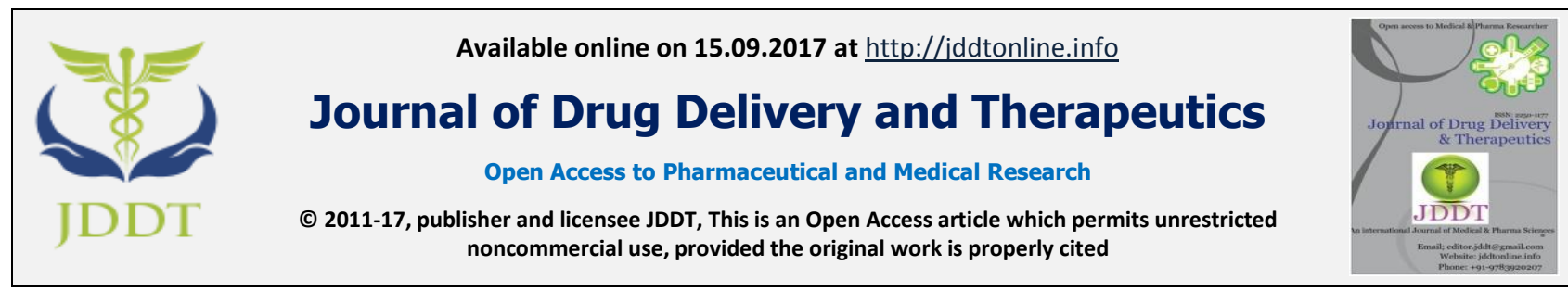

Open $\odot$ Access

Research Article

\title{
ANTI-ARTHRITIC EVALUATION OF SOME TRADITIONALLY USED MEDICINAL PLANTS IN FCA INDUCED ARTHRITIS IN RATS
}

\author{
Mr. Om Prakash Tiwari ${ }^{1 *}$, Dr. Manoj Sharma ${ }^{2}$ \\ ${ }^{1}$ Research Scholar, Pacific University, Pacific Hills, Udaipur, Rajasthan, India \\ ${ }^{2}$ School of pharmacy, Jiyaji University, Gwalior, (M.P.), India
}

\section{ABSTRACT}

Aim of Study: The main of study is to evaluate the anti-arthritic activity of some Traditionally Used Medicinal Plants in FCA Induced Arthritis in Rats.

Material \& Methods: All the selected medicinal plants were extracted by using methanol using soxhlet apparatus. Arthritis was induced by FCA in rats and body weight; hematological parameters were measured at the end of experiment.

Results: The assessment made on the $21^{\text {st }}$ day showed that the $N$. arbor-tristis and A. scholaris treatments at both doses (low and high) had moderately significant and highly significant effect and reduced $(p<0.01 \& p<0.001)$. N. arbor-tristis, A. scholaris had highly significant effects $(p<0.001)$ in recovery of RBCs and hemoglobin. They also showed highly significant effects on decrease in WBCs and ESR. B. monosperma and B. diffusa extract treated groups, also showed moderately significant effects as compared to arthritic group.

Conclusion: By comparing the results of the selected plants in FCA induced arthritis, it could be concluded that methanolic extracts of Nyctanthes arbor-tristis, Alstonia scholaris and Butea monosperma have most potent and highly significant anti-arthritic activity.

Keywords: Nyctanthes arbortristis, Butea monosperma, Alstonia scholaris, Arthritis, Arthritic Assessment

Article Info: Received 28 May, 2017; Review Completed 13 July, 2017; Accepted 31 Aug, 2017; Available online 15 Sep, 2017

Cite this article as:

Tiwari OP, Sharma M, Anti-arthritic evaluation of some traditionally used medicinal plants in FCA induced arthritis in rats, Journal of Drug Delivery and Therapeutics. 2017; 7(5):74-79

DOI: http://dx.doi.org/10.22270/jddt.v7i5.1475

*Address for Correspondence

Om Prakash Tiwari, Research Scholor, Pacific University, Pacific Hills, Udaipur, Rajasthan, India

\section{INTRODUCTION}

Conventional (allopathic) anti-inflammatory drugs are the mainstay of treatment for rheumatic diseases. However in wake of the side effects and the high cost of conventional therapy; people have increasingly started exploring alternative measures to treat the disease. These alternative treatments have been used both, as adjunct and an alternative to conventional therapy ${ }^{1}$ (Koehn \& Carter, 2006).

Recently, natural herbal medicines have been widely applied for human beings. Several medicinal herbs have been shown to promote and suppress immunity in different ways and augments specific cellular and humoral response ${ }^{2}$ (Wagner, 1990).

As per the literature review, it has been observed that Nyctanthes arbor-tristis (leaf), Alstonia scholaris (leak and bark), Butea monosperma (flower) and Boerhaavia diffusa (root) are listed among the various medicinal plants widely been used in the acute and chronic inflammatory conditions. The literature review also suggested that these medicinal plants have been shown to have Immunomodulatory activity ${ }^{3,4}$ (Kirtikar \& Basu, 2006; Nadkarni, 2002).

There is no preliminary scientific study is available which claims for their anti-arthritic activity in chronic inflammatory conditions. Hence, there is a need in 
scientifically establishing the anti-arthritic activity of selected medicinal plants.

\section{MATERIAL \& METHODS}

\section{Collection and authentication of the plant materials}

The leaves of Nyctanthes arbor-tristis and Alstonia scholaris and roots of Boerhaavia diffusa and flowers of Butea monosperma were collected from outfield and also purchased from local markets. Plant was identified by the Botanist, Research Officer; Botany (Scientist C) at Central Council for Research in Ayurveda, Govt. of India.

\section{Preparation of Total Crude Extract}

Accurately weighed quantity of leaf powder of Nyctanthes arbor-tristis and Alstonia scholaris, dried flowers of Butea monosperma and roots of Boerhaavia diffusa were defatted by using petroleum ether. The mark were dried, weighed and then again extracted by using methanol by soxhlet apparatus for $72 \mathrm{~h}$. The extract of all plants were dried completely under reduced pressure and finally converted into powder. After drying, the respective extracts were weighed and percentage yield was determined ${ }^{5}$ (Mukherjee, 2002).

\section{Preliminary Phytochemical Tests}

Qualitative chemical tests of Methanolic extracts were subjected to various chemical tests to detect various phytoconstituents $^{6,7}$ (Kokate, 2003; Khandelwal, 2006).

\section{Preliminary in-vivo anti-arthritic activity}

\section{Selection of animals}

Wistar albino rats of either sex between 2 and 3 months of age weighing 150-200 g were used which were procured from the central animal house. All animals were housed in an animal room under normal condition of $25 \pm 1^{0} \mathrm{C}, 12-\mathrm{h}$ light and dark cycle. All the experimental procedures were carried out in accordance with the Committee for the Purpose of Control and Supervision of Experiments on Animals (CPCSEA) guidelines. The study designs were approved by the Institutional Animal Ethical Committee.

\section{Acute toxicity studies}

The acute oral toxicity studies were carried out according to the guidelines set by the Organization for Economic Co-operation and Development (OECD), revised draft guideline 423 .

Methanolic extract was prepared as a suspension by triturating dried extracts with $1 \%$ Tween 80 , prepared in distilled water. Extracts of all plants were administered orally to albino rats at dose of $2000 \mathrm{mg} / \mathrm{kg}$. In first step each dose was tested on single rat and then administered to other four rats. Observation was made during the first four hours after the drug administration to notice change in skin and fur, eye, mucus membrane, hyperactivity, grooming, convulsions, sedation, hypothermia, tremor, salivation, coma, lethargy, body weight, and mortality up to 14 days.
One tenth and one fifth of the lethal dose was taken as effective dose (therapeutic dose) and cut off value was selected as 200 and $400 \mathrm{mg} / \mathrm{kg}$ to evaluate the dose dependent action for the evaluation of anti-arthritic activity (OECD guidelines, 2001) ${ }^{8}$.

\section{Evaluation of anti-arthritic activity}

FCA $(0.1 \mathrm{ml})$ was injected through intra-articular injection in left ankle joint of rats on 0 day. Preinduction baseline was taken prior to the injection of Freund's Complete Adjuvant (FCA) measured by left paw volume of each animal at 0 day for the induction of arthritis in Wistar rats. The treatments with all plant extracts were given once daily from day of injection to $21^{\text {st }}$ day. A suspension of the test extracts were prepared in $1 \%$ Tween 80 .The animal groups are as follows ${ }^{9}$ (Arulmozhi et al., 2011).

Group-I: Arthritic control, treated with $0.1 \mathrm{~mL}$ of FCA on zero day.

Group-II: Standard control: treated with prednisolone $(10 \mathrm{mg} / \mathrm{kg}$, p.o. $)+$ FCA

Group-III: Treated with methanolic extracts of $N$. arbor-tristis $(200 \mathrm{mg} / \mathrm{kg}$, p.o.) + FCA

Group-IV: Treated with methanolic extracts of $N$. arbor-tristis $(400 \mathrm{mg} / \mathrm{kg}$, p.o.) + FCA

Group-V: Treated with methanolic extracts of $A$. scholaris $(200 \mathrm{mg} / \mathrm{kg}$, p.o.) + FCA

Group-VI: Treated with methanolic extracts of $A$. scholaris $(400 \mathrm{mg} / \mathrm{kg}$, p.o. $)+$ FCA

Group-VII: Treated with methanolic extracts of $B$. monosperma $(200 \mathrm{mg} / \mathrm{kg}$, p.o. $)+\mathrm{FCA}$

Group-VIII: Treated with methanolic extracts of $B$. monosperma (400 mg/kg, p.o.) + FCA

Group-IX: Treated with methanolic extracts of $B$. diffusa $(200 \mathrm{mg} / \mathrm{kg}$, p.o. $)+$ FCA

Group-X: Treated with methanolic extracts of $B$. diffusa $(400 \mathrm{mg} / \mathrm{kg}$, p.o. $)+$ FCA

\section{Measurements of paw volume}

Paw volume $(\mathrm{ml})$ was measured at 0 days and thereafter $4,8,12,16$ and 21 days of FCA post-inoculation. The percentage inhibition of paw volume was measured by following formula ${ }^{9}$ (Arulmozhi et al., 2011; Ignacimuthu et al., 2011).

Percentage inhibition $=\mathrm{Vc}-\mathrm{Vt} / \mathrm{Vt} \times 100$

Where,

Vc-Paw volume of control animals

Vt-Paw volume of treated animals

\section{Measurements of body weight}

Body weight was measured of all groups at zero days before immunization and at $21^{\text {st }}$ day after treatments over by using a single pan weighing balance ${ }^{11}$ (Jalalpure et al., 2011). 


\section{Measurements of hematological parameters}

On the 21st day after arthritis induction, rats were anaesthetized with ether and blood samples were collected into Ethylenediamine tetra-acetic acid (EDTA)-coated tubes from retro orbital junction. The number of leukocytes from each rat was determined using a counting chamber (celldyn-1200, Abbott Carepam). Erythrocyte sedimentation rate (ESR) was determined using the Wintrobe method. RBCs and Haemoglobin were determined by routine laboratory method $^{11}$ (Jalalpure et al., 2011).

\section{Statistical Analysis}

The values are expressed in mean \pm SEM. The results were analyzed by using one way analysis of variance (ANOVA) followed by Dunnet's " $t$ " test to determine the statistical significance. $p<0.05$ was chosen as the level of significance.

\section{RESULT}

\section{Preliminary Phytochemical Screening}

The preliminary phytochemical analysis revealed that different active constituent present in different extracts such as carbohydrates, proteins, amino acids, fat, oils, steroids, terpenoids, glycosides, alkaloids, tannins and other phenolics compounds.

\section{Acute Toxicity Studies of Plant Extracts}

No toxic effects were observed at a higher dose of 2000 $\mathrm{mg} / \mathrm{kg}$ body weight of Wistar rats. Hence, 1/ 10th dose was selected as effective dose or therapeutic dose. The cut off value of 200 and $1 / 5$ dose double of $400 \mathrm{mg} / \mathrm{kg}$ were selected for anti-arthritic and anti-inflammatory activity.

\section{Anti-arthritic activity of different plant extracts}

\section{Freund's complete adjuvant induced rat paw edema}

Paw volume were recorded on $4^{\text {th }}, 8^{\text {th }}, 12^{\text {th }}, 16^{\text {th }}, 21^{\text {st }}$ day after adjuvant injection. The CFA-induced arthritic control group showed signs of arthritis development, as seen by the increase in the paw volume and other indications, such as decreased body weight, also showed induction of arthritis in the CFA-treated control group rats. The assessment made on the $21^{\text {st }}$ day showed that the N. arbor-tristis and A. scholaris treatments at both doses (low and high) had moderately significant and highly significant effect and reduced $(p<0.01 \&$ $p<0.001)$ the adjuvant-induced lesions in the respective treatment groups as compared with the arthritis control group. However, treatments of Butea monosperma and Boerhaavia diffusa had moderately significant effects $(p<0.01)$ in treated group as compared to arthritic control.

Table No 1: Effects of extracts on paw volume in FCA induced arthritis in rat

\begin{tabular}{|c|c|c|c|c|c|c|c|}
\hline \multirow{2}{*}{$\begin{array}{l}\text { S. } \\
\text { No. }\end{array}$} & \multirow[b]{2}{*}{$\begin{array}{l}\text { Groups \& } \\
\text { Treatments }\end{array}$} & \multicolumn{6}{|c|}{ Paw Volume in $\mathbf{~ m L}$} \\
\hline & & Zero Day & $4^{\text {th }}$ Day & $8^{\text {th }}$ Day & $12^{\text {th }}$ Day & $16^{\text {th }}$ Day & $21^{\text {st }}$ Day \\
\hline 1 & Normal Control & $0.28 \pm 0.08$ & $0.30 \pm 0.03$ & $0.30 \pm 0.04$ & $0.31 \pm 0.03$ & $0.31 \pm 0.04$ & $0.31 \pm 0.15$ \\
\hline 2 & $\begin{array}{l}\text { Arthritic Control, } \\
1 \% \text { Tween } 80 \text {, p.o. }\end{array}$ & $0.32 \pm 0.02$ & $0.51 \pm 0.04 * *$ & $\begin{array}{c}0.86 \pm 0.01 * * \\
*\end{array}$ & $\begin{array}{c}0.93 \pm 0.03 * \\
* *\end{array}$ & $\begin{array}{c}1.30 \pm 0.06^{*} \\
* *\end{array}$ & $\begin{array}{c}1.62 \pm 0.01 * \\
* *\end{array}$ \\
\hline 3 & $\begin{array}{l}\text { Prednisolone } 10 \\
\mathrm{mg} / \mathrm{kg} \text {, p.o. }\end{array}$ & $0.31 \pm 0.04$ & $0.32 \pm 0.03 *$ & $0.41 \pm 0.15^{* *}$ & $\begin{array}{c}0.44 \pm 0.03 * \\
* *\end{array}$ & $\begin{array}{c}0.50 \pm 0.04 * \\
* *\end{array}$ & $\begin{array}{c}0.54 \pm 0.05 * \\
* *\end{array}$ \\
\hline 4 & $\begin{array}{l}\text { N. arbor-tristis, } \\
200 \mathrm{mg} / \mathrm{kg} \text {, p.o. }\end{array}$ & $0.30 \pm 0.10$ & $0.41 \pm 0.02$ & $0.51 \pm 0.01 *$ & $0.61 \pm 0.02 *$ & $\begin{array}{c}0.67 \pm 0.03 * \\
*\end{array}$ & $\begin{array}{c}0.73 \pm 0.04 * \\
* *\end{array}$ \\
\hline 5 & $\begin{array}{l}\text { N. arbor-tristis, } \\
400 \mathrm{mg} / \mathrm{kg} \text {, p.o. }\end{array}$ & $0.31 \pm 0.03$ & $0.42 \pm 0.02$ & $0.46 \pm 0.01 *$ & $\begin{array}{c}0.54 \pm 0.04 * \\
*\end{array}$ & $\begin{array}{c}0.62 \pm 0.01 * \\
* *\end{array}$ & $\begin{array}{c}0.64 \pm 0.02 * \\
* *\end{array}$ \\
\hline 6 & $\begin{array}{l}\text { A. scholaris, } \\
200 \mathrm{mg} / \mathrm{kg} \text {, p.o. }\end{array}$ & $0.30 \pm 0.06$ & $0.43 \pm 0.05$ & $0.53 \pm 0.01 *$ & $0.62 \pm 0.05 *$ & $\begin{array}{c}0.71 \pm 0.09 * \\
*\end{array}$ & $\begin{array}{c}0.76 \pm 0.14 * \\
*\end{array}$ \\
\hline 7 & $\begin{array}{l}\text { A. scholaris, } \\
400 \mathrm{mg} / \mathrm{kg} \text {, p.o. }\end{array}$ & $0.32 \pm 0.04$ & $0.41 \pm 0.12$ & $0.51 \pm 0.02 *$ & $\begin{array}{c}0.57 \pm 0.02 * \\
*\end{array}$ & $\begin{array}{c}0.61 \pm 0.02 * \\
*\end{array}$ & $\begin{array}{c}0.67 \pm 0.02 * \\
* *\end{array}$ \\
\hline 8 & $\begin{array}{l}\text { B. monosperma, } \\
200 \mathrm{mg} / \mathrm{kg} \text {, p.o. }\end{array}$ & $0.30 \pm 0.04$ & $0.48 \pm 0.16$ & $0.67 \pm 0.02$ & $0.71 \pm 0.04 *$ & $\begin{array}{c}0.81 \pm 0.01 * \\
*\end{array}$ & $\begin{array}{c}0.84 \pm 0.03 * \\
*\end{array}$ \\
\hline 9 & $\begin{array}{l}\text { B. monosperma, } \\
400 \mathrm{mg} / \mathrm{kg} \text {, p.o. }\end{array}$ & $0.31 \pm 0.02$ & $0.44 \pm 0.11$ & $0.61 \pm 0.03$ & $\begin{array}{c}0.67 \pm 0.04 * \\
* \\
\end{array}$ & $\begin{array}{c}0.76 \pm 0.06 * \\
* *\end{array}$ & $\begin{array}{c}0.82 \pm 0.06^{*} \\
* *\end{array}$ \\
\hline $\mathbf{1 0}$ & $\begin{array}{l}\text { B. diffusa, } \\
200 \mathrm{mg} / \mathrm{kg} \text {, p.o. }\end{array}$ & $0.30 \pm 0.04$ & $0.48 \pm 0.13$ & $0.70 \pm 0.002$ & $0.75 \pm 0.10 *$ & $\begin{array}{c}0.82 \pm 0.06 * \\
*\end{array}$ & $\begin{array}{c}0.88 \pm 0.01 * \\
*\end{array}$ \\
\hline 11 & $\begin{array}{l}\text { B. diffusa, } \\
400 \mathrm{mg} / \mathrm{kg} \text {, p.o. }\end{array}$ & $0.31 \pm 0.08$ & $0.47 \pm 0.04$ & $0.68 \pm 0.11 *$ & $\begin{array}{c}0.70 \pm 0.03 * \\
* \\
\end{array}$ & $\begin{array}{c}0.76 \pm 0.02 * \\
*\end{array}$ & $\begin{array}{c}0.80 \pm 0.11 * \\
* * \\
\end{array}$ \\
\hline
\end{tabular}

Values are expressed as mean \pm SEM, $n=6$ in each group; $* p<0.05$, compared to disease control $* * p<0.01$, compared to disease control. $* * * p<0.001$, compared to disease control 


\section{Effects on body weight}

Although the weights were almost identical in all group of animals at 0 to 7 days during the subsequent course of disease, the body weight always declined in arthritic control group from $14^{\text {th }}$ day to $21^{\text {st }}$ day. In arthritic group, decrease in body weight were observed on the subsequent days, whereas groups treated with standard, extracts of $N$. arbor-tristis, A. scholaris, B. monosperma and $B$. diffusa showed improvements in body weight. All the extracts had moderately and highly significant increase in body weight $(p<0.01 \& p<0.001)$ as compared to arthritic rats.

Table 2: Effects of plant extracts on body weight in FCA induced arthritis in rat

\begin{tabular}{|c|c|c|c|}
\hline \multirow[t]{2}{*}{ S. No. } & \multirow[t]{2}{*}{ Groups \& Treatments } & \multicolumn{2}{|c|}{ Days } \\
\hline & & Zero & $21^{\text {st }}$ \\
\hline $\mathbf{1}$ & Normal Control & $191.20 \pm 0.72$ & $191.47 \pm 0.30$ \\
\hline 2 & Arthritic Control, $1 \%$ Tween 80, p.o. & $192.40 \pm 0.14$ & $165.18 \pm 0.21 * * *$ \\
\hline 3 & Prednisolone, $10 \mathrm{mg} / \mathrm{kg}$, p.o. & $191.80 \pm 0.22$ & $216.30 \pm 0.12 * * *$ \\
\hline 4 & N. arbor-tristis, $200 \mathrm{mg} / \mathrm{kg}$, p.o. & $192.18 \pm 0.41$ & $208.20 \pm 0.13 * *$ \\
\hline 5 & N. arbor-tristis, $400 \mathrm{mg} / \mathrm{kg}$, p.o. & $190.20 \pm 0.56$ & $212.40 \pm 0.04 * * *$ \\
\hline 6 & A. scholaris, $200 \mathrm{mg} / \mathrm{kg}$, p.o. & $190.18 \pm 0.11$ & $207.40 \pm 0.12 * *$ \\
\hline 7 & A. scholaris, $400 \mathrm{mg} / \mathrm{kg}$, p.o. & $192.25 \pm 0.41$ & $210.60 \pm 0.03 * * *$ \\
\hline 8 & B. monosperma, $200 \mathrm{mg} / \mathrm{kg}$, p.o. & $192.10 \pm 0.63$ & $206.35 \pm 0.01 * *$ \\
\hline 9 & B. monosperma, $400 \mathrm{mg} / \mathrm{kg}$, p.o. & $191.50 \pm 0.24$ & $208.60 \pm 0.13 * *$ \\
\hline 10 & B. diffusa, $200 \mathrm{mg} / \mathrm{kg}$, p.o. & $192.65 \pm 0.35$ & $201.30 \pm 0.13^{*}$ \\
\hline 11 & B. diffusa, $400 \mathrm{mg} / \mathrm{kg}$, p.o. & $191.30 \pm 0.12$ & $205.80 \pm 1.11 * *$ \\
\hline
\end{tabular}

Values are expressed as mean \pm SEM, $n=6$ in each group; ${ }^{*} p<0.05$, compared to disease control $* * p<0.01$, compared to disease control. $* * * p<0.001$, compared to disease control

\section{Effects on haematological parameters}

As shown in figure 1-4, FCA-induced arthritic rats at $21^{\text {st }}$ day showed elevation in the total WBC count and reduction in RBC. However, significantly $(p<0.001)$ increased ESR while the haemoglobin was significantly $(p<0.001)$ reduced in the control group when compared with normal group. However, standard, and N. arbortristis, A. scholaris had highly significant effects $(p<0.001)$ in recovery of RBCs and haemoglobin. They also showed highly significant effects on decrease in WBCs and ESR. B. monosperma and B. diffusa extract treated groups, also showed moderately significant effects as compared to arthritic group.
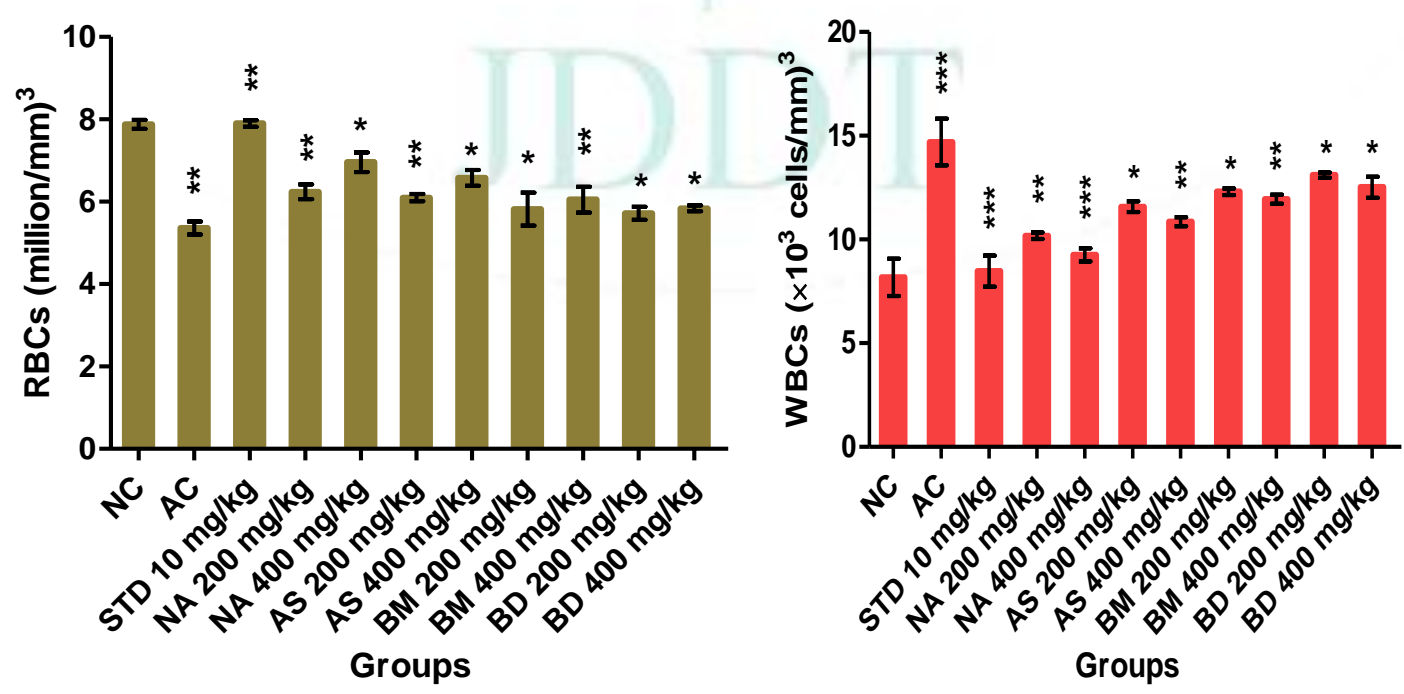

Figure 1: Effects of extracts on RBCs Figure 2: Effects of extracts on WBCs 


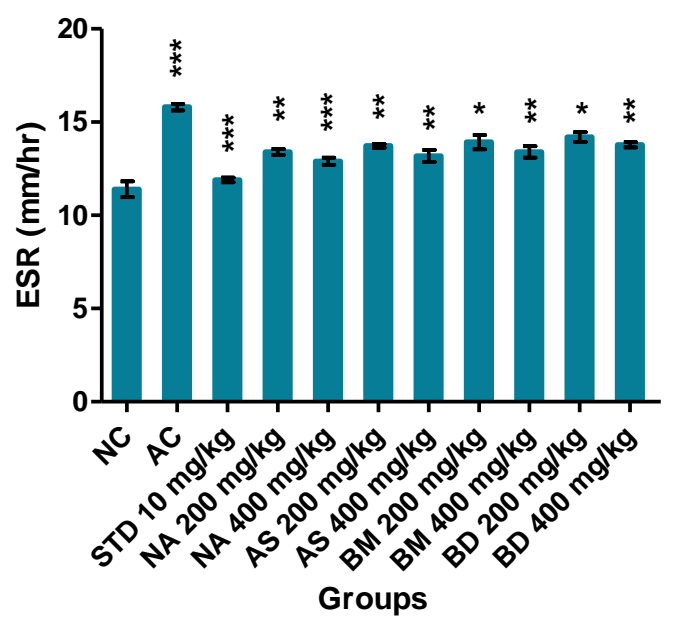

Figure 3: Effects of extracts on ESR

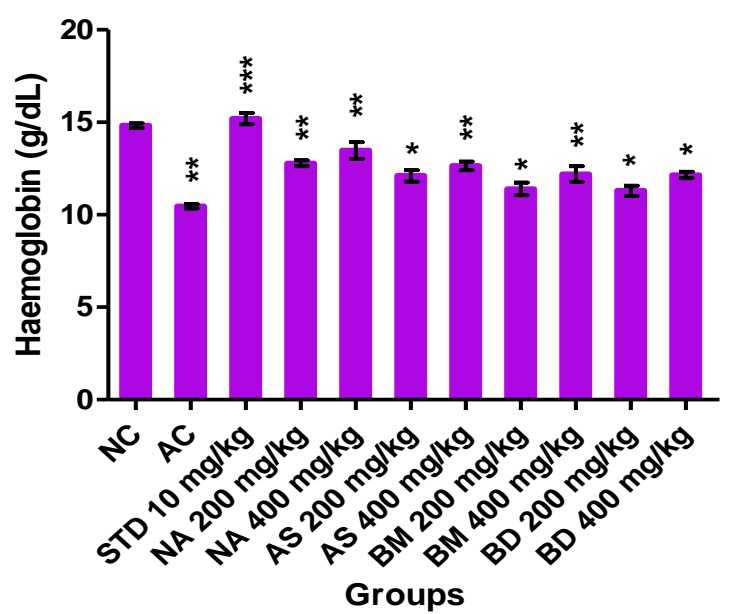

Figure 4: Effects of extracts on $\mathrm{Hb}$

\section{DISCUSSION}

Rheumatoid arthritis (RA) is a chronic inflammatory disease which leads to the destruction of synovial membranes, cartilage and bone. Although etiology and pathogenesis of RA is poorly understood, proinflammatory cytokines are considered to be one of the most important mediators involved in the pathogenesis of RA. Mclnnes et al., compiled the recent investigations of this subject thoroughly and discussed the role of cytokines in RA ${ }^{12}$ (Mclnnes \& Schett, 2007).

CFA-induced experimental model for arthritis is considered closest to simulating human rheumatoid arthritis and therefore it is the most widely used chronic test model in which the associated clinical and Histopathological changes are comparable to those seen in human form ${ }^{13,14}$ (Billingham \& Davies, 1979; Butler et al., 1992).

The results emanating from the present study demonstrated that the test extracts of Nyctanthes arbortristis, Alstonia scholaris, Butea monosperma and Boerhaavia diffusa dose dependently attenuated chronic inflammatory responses in adjuvant induced arthritis and also facilitated recovery as measured by the decreasing paw edema, body weight and various haematological parameters.

Treatment with all test extracts of selected plants showed dose dependent suppression in edema of the injected paw (primary lesions). Our study results reveal that extracts of Nyctanthes arbor-tristis and Alstonia scholaris treated rats significantly reduced the paw volume as compared to animals treated by extracts of Butea monosperma and Boerhaavia diffusa. Boerhaavia diffusa showed less effect as compared to all other plants.

During the development of arthritic syndrome, the body weight of rats used as an indirect index in restoration of health. The body weight was significantly decreased in arthritic rat as compared to normal rat, but in the test extracts and standard drug treated groups, the body weights of the rats did not decline. The results of our study therefore indicated that there is a relationship between the extent of inflammation and loss of body weight. As the incidence and severity of arthritis increase, the changes in the body weights of the rats also occur during the course of the experimental period ${ }^{15}$ (Wilder et al., 1999). In our study, the body weight was significantly increased in the groups treated with prednisolone and all the extracts treated groups and this may be due to the restoration of absorption capacity of intestine. From our results, it can be concluded that all the extracts possess potentially useful anti-arthritic activity since they give a positive result in controlling inflammation in adjuvant-induced arthritis in rats.

With the development of arthritic conditions, there was a significant alteration of haematological parameters i.e. red blood cells (RBCs), white blood cells (WBCs), Haemoglobin $(\mathrm{Hb})$ and erythrocyte sedimentation rate (ESR). As the disease progressed, RBCs and haemoglobin were decreased whereas; WBCs and ESR were significantly increased in arthritic control group when treated with normal control.

The results of our study revealed that all the extracts treated group's causes significant alterations in the hematological parameters and maximal effects were observed at $400 \mathrm{mg} / \mathrm{kg}$. The reversal of RBC counts and $\mathrm{Hb}$ levels observed in case of test extract treated groups could be attributed to the protective effects on tissue repair and suppression of disease progression. By modulation of immune system, all the extracts and prednisolone treated groups normalize the WBCs and ESR.

In previous literature, a lots of biologically active phytocompounds such as steroids, flavonoids, alkaloids, terpenoids, glycosides, tannins and phenolic compounds are reported to be responsible for significant antiarthritic and anti-inflammatory activity ${ }^{16,17,18,19,20}$ (Liu et al., 1996; Singh et al., 2002; Agarwal \& Rangari, 2003; Elmali et al., 2005; Amresh et al., 2007). 
In our phytochemical screening, all the extracts had shown the presence of active phytocompounds i.e. steroids, terpenoids, alkaloids, flavonoids, glycosides and fatty acids.

Preliminary anti-arthritic activity of selected plants extracts was clearly demonstrated that all the selected plants have significant anti-arthritic activity and presence of aforementioned phytocompounds in the extracts may be responsible for the anti-arthritic activity.

\section{CONCLUSION}

By comparing the results of the selected plants in FCA induced arthritis, it could be concluded that methanolic extracts of Nyctanthes arbor-tristis, Alstonia scholaris and Butea monosperma have most potent and highly significant anti-arthritic activity.

\section{REFERENCES}

1. Koehn, F.E., and Carter, G.T., 2005. The evolving role of natural products in drug discovery. Nature Reviews, Vol. 4, pp. 206-220.

2. Wagner, H., Geyer, B., Fiebig, M., Kiso, Y., Hikino, H., "Isobutrin and Butrin, the Antihepatotoxic Principles of Butea Monosperma Flowers", Planta Medica.1986;52(2):7779

3. Kirtikar, K.R. and Basu, B.D., 2006. Indian Medicinal Plants. India, International Book Distributors Book Sellers \& Publisher.

4. Nadkarni, K.M., 2002. Indian Materia Medica. Mumbai, Bombay Popular Prakashan.

5. Mukherjee, P.K., 2002. Quality Control of Herbal Drugs-an Approach to Evaluation of Botanicals. New Delhi, Business Horizons Pharmaceutical Publishers.

6. Kokate, C.K., 1996, Practical Pharmacognosy. Delhi, Vallabh Prakashan.

7. Khandelwal, K.R., 2006. Practical Pharmacognosy. Pune, Nirali Prakashan.

8. OECD Guidelines 2001. "Guidance document on acute oral toxicity testing" Series on testing and assessment No. 23, Organization for Economic Co-operation and Development, OECD Environment, health and safety publications, Paris Available from: http://www. Oecd.org/ehs [accessed 20 March on 2010].
9. Arulmozhi, S., Mazumdar, P.M., Purnima, A., Basavaraj, H., Sathiyanarayan, L., 2007. Antinociceptive and antiinflammatory activity of Alstonia scholaris Linn. R. Br. Pharmacognosy Magazine, Vol. 3, Issue 10, pp. 106-111.

10. Ignacimuthu, S., Babu, N.P., Pandikumar, P., 2011. Lysosomal membrane stabilization and anti-inflammatory activity of Clerodendrum phlomidis L.f., a traditional medicinal plant. Journal of Ethnopharmacology, Vol. 135, Issue 3, pp. 779-785.

11. Jalalpure, S.S., Yuvaraj, D., Mandavkar, P.R., Khalure, G.S., Shinde, P., Shelar, A., Shah, A.S., 2011. Anti-arthritic activity of various extracts of Mesua ferrea Linn. Seed. Journal of Ethnopharmacology, Vol. 138, Issue 3, pp. 700704.

12. Mclnnes, I.B. and Schett, G., 2007. Cytokines in the pathogenesis of rheumatoid arthritis. Nature Reviews Immunology, Vol. 7, Issue 6, pp. 429-442.

13. Billingham, M.E.J. and Davies, G.E., 1979. Experimental models of arthritis in animals as screening tests for drugs to treat arthritis in man. Handbook of Experimental Pharmacology, Vol. 50, Issue 2, pp. 108-44.

14. Butler, S.H., Godefroy, F., Besson, J.M., Weil-Fugazza, J., 1992. A limited arthritic model for chronic pain studies in the rat. Pain, Vol. 48, Issue 1, pp. 73-81.

15. Wilder, R.L. and Bina, J., 1999. Animal models of rheumatoid arthritis. Molecular Medicine Today, Vol. 5, pp. 367-69.

16. Liu, L., Buchner, E., Beitze, D., Schmidt-Weber, C.B., Kaever, V., Emmrich, F., Kinne, R.W., 1996. Amelioration of rat experimental arthritides by treatment with the alkaloid sinomenine. International Journal of Immunopharmacology, Vol. 18, Issue 10, pp. 529-543.

17. Singh, B., Sahu, P.M., Sharma, M.K., 2002. Antiinflammatory and antimicrobial activities of triterpenoids from Strobilanthes callosus Nees. Phytomedicine, Vol. 9, Issue 4, pp. 355-359.

18. Agarwal, R.B. and Rangari, V.D., 2003. Phytochemical investigation and evaluation of anti inflammatory and antiarthritic activities of essential oil of Strobilanthus ixiocephala Benth. Indian Journal of Experimental Biology, Vol. 41, Issue 8, pp. 890-894.

19. Elmali, N., Esenkaya, I., Harma, A., Ertem, K., Turkoz, Y., Mizrak, B., 2005. Effect of resveratrol in experimental osteoarthritis in rabbits. Inflammation Research, Vol. 54, Issue 4, pp. 158-162.

20. Amresh, G., Singh, P.N., Rao, C.V., 2007. Antinociceptive and anti-arthritic activity of Cissampelos pareira roots. Journal of Ethnopharmacology, Vol. 111, Issue 3, pp. 531536. 